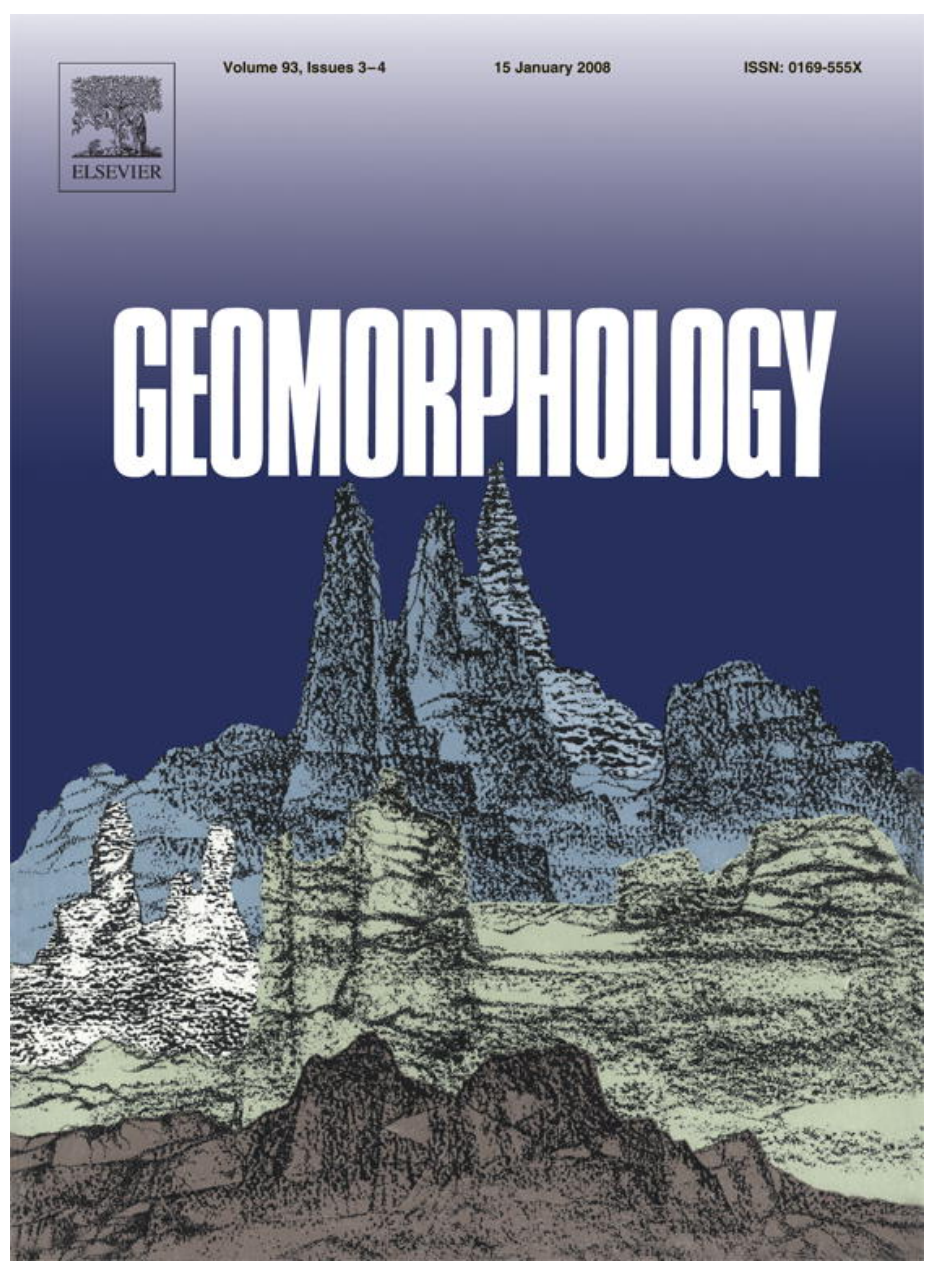

This article was published in an Elsevier journal. The attached copy

is furnished to the author for non-commercial research and education use, including for instruction at the author's institution, sharing with colleagues and providing to institution administration.

Other uses, including reproduction and distribution, or selling or licensing copies, or posting to personal, institutional or third party websites are prohibited.

In most cases authors are permitted to post their version of the article (e.g. in Word or Tex form) to their personal website or institutional repository. Authors requiring further information regarding Elsevier's archiving and manuscript policies are encouraged to visit: 


\title{
Relative size of fluvial and glaciated valleys in central Idaho
}

\author{
Byron E. Amerson $^{\mathrm{a}, *}$, David R. Montgomery ${ }^{\mathrm{b}}$, Grant Meyer ${ }^{\mathrm{c}}$ \\ ${ }^{a}$ Stillwater Watershed, Ecosystem, and Riverine Sciences, Inc., Seattle, WA, 98105, USA \\ ${ }^{\mathrm{b}}$ Department of Earth and Space Sciences, University of Washington, Seattle WA 98195, USA \\ ${ }^{\mathrm{c}}$ Department of Earth and Planetary Sciences, University of New Mexico, Albuquerque, NM 87131, USA
}

Received 28 March 2007; accepted 2 April 2007

Available online 6 April 2007

\begin{abstract}
Quantitative comparisons of the morphometry of glaciated and fluvial valleys in central Idaho were used to investigate the differences in valley relief and width in otherwise similar geologic and geomorphic settings. The local relief, width, and crosssectional area of valleys were measured using GIS software to extract information from USGS digital elevation models. Hillslope gradients were also measured using GIS software. Power-law relationships for local valley relief, width, and cross-sectional area as a function of drainage area were developed. Local valley relief in glaciated valleys relates to drainage area with a power-law exponent similar to fluvial valleys, but glaciated valleys are deeper for a given drainage area. Local valley width in glaciated valleys is greater than in fluvial valleys, but the exponent of the power-law relationship to drainage area is similar in both valley types. Local valley cross-sectional area in glaciated valleys increases with drainage area with a power-law exponent similar to fluvial valleys, however, glacial valleys have roughly $80 \%$ greater cross-sectional area. Steep valley walls in glaciated basins increase the potential for bedrock landsliding relative to fluvial basins. Both the Olympic Mountains of Washington and valleys in central Idaho show relationships in which glaciated valleys are up to $30 \%$ deeper than fluvial valleys despite differences in lithology, tectonic setting, and climate.
\end{abstract}

(C) 2007 Elsevier B.V. All rights reserved.

Keywords: Idaho; Glacial; Fluvial; Erosion; Morphometry; Relief; Valley

\section{Introduction}

Understanding the physical form of glaciated valleys is necessarily rooted in theories on how glacial erosion functions. The physical form of a glaciated valley is the product of the interaction between the effectiveness of erosion by glacier ice and the resistance to erosion and the structure of the country rock in which the glaciated valley resides. There are three broad aspects of glaciated valley morphometry that have been the focus of

\footnotetext{
* Corresponding author.

E-mail address: byron@stillwatersci.com (B.E. Amerson).
}

research: rates of sediment evacuation and relief development (Small and Anderson, 1998; Whipple et al., 1999; Brocklehurst and Whipple, 2002, Montgomery, 2002b, Koppes and Hallet, 2006; Mitchell and Montgomery, 2006; Oskin and Burbank, 2005), development of the longitudinal profile (e.g. MacGregor et al., 2000), and development of cross-sectional form (e.g. Harbor, 1995; Augustinus, 1995).

Studies on the cross-sectional form of glaciated valleys have used "form parameters" including depthto-width ratio (form ratio) and the value of coefficients of quadratic or power-law equations fitted to valley wall profiles to empirically describe glacial valley 
morphology and regional distinctions (e.g. Harbor, 1992). The use of form parameters has allowed comparison between valley morphologies to help understand erosional histories and investigate ways in which variations in climate, erosional processes, and regional lithology influence the character of particular terrain.

The prior erosional history of a valley has important implications for the pattern of erosion by a glacier. For instance, Harbor (1992) has shown that a valley that is $\vee$ shaped in profile (ostensibly generated by fluvial processes) is initially subjected to greater erosion along its margins than along its bottom when occupied by a glacier than in a valley that is already $\cup$ shaped. The volume of sediment present on the valley floor has an influence on subsequent erosion by either glaciers or rivers because it retards bedrock erosion and thus bed lowering. Valley bottom sediment volume also can affect the shape of valley cross-sectional profiles. Seismic data from Yosemite Valley in the Sierra Nevada show that glaciated valleys can be filled with substantial deposits of sediment, which can mask the total relief of the bedrock surface (Gutenberg et al., 1956).

The volume of sediment stored in the valley bottom can affect analysis of form parameters as well. The exponent of a power-law function fit to cross-sectional profiles has been shown to be sensitive to the bedrock datum used to fit them, and so knowing the true bedrock profile that is buried by valley bottom sediment is paramount if meaningful comparisons between studies are to be made when considering form parameters (Harbor, 1992).

Here we quantitatively analyze and compare the relief and width of glaciated and fluvial valleys in central Idaho to define morphometric relationships among valley characteristics. As relief has been described in various ways in the literature (Montgomery, 2002a), we consider local valley relief measured at specific sites in a valley to consist of the elevation difference between the valley floor and the mean elevation of the subtending ridgelines. We define glaciated valleys as valleys that were occupied by glaciers during the last glaciation, as shown by littlemodified lateral and terminal moraines along many lower margins, and by a large proportion of valley area above the regional late Pleistocene equilibrium line altitude (ELA) (Meyer et al., 2004). It is probable that the drainage network and density of our glaciated valleys were initially set by fluvial processes prior to the onset of Quaternary glaciation, and that following deglaciation, fluvial processes have again become the dominant form of bed erosion in glaciated valleys, so that the present form of these valleys is the result of a complex erosional history. Hence, we seek to evaluate the degree to which glacial erosion modified valley size. The specific aim of the research is to investigate the relationship of valley morphometry (local relief, width, and cross-sectional area) with drainage area in glaciated and fluvial basins. This work focuses not on specific mechanisms of valley formation, but on the net result of these erosional processes.

\section{Glacial erosion processes and valley formation}

Glacial erosion is considered to consist of four components: abrasion, plucking, dissolution, and scour by subglacial meltwater. Mechanistic models for the first two components of glacial erosion are relatively advanced (e.g., Hallet, 1979, 1996), but erosion by subglacial meltwater and dissolution are less well understood (Goudie, 2002). In general, all of these processes are influenced by whether the glacier is frozen to its bed-in which case the ice moves by internal deformation alone, and the bed remains unaffected. Large, alpine glaciers in temperate latitudes are generally wet-based and therefore not frozen to their beds because of moderate climate and pressure melting of ice at the bed of the glacier. In contrast, in polar latitudes, or during periods of cold climate, freezing of glaciers to their beds is possible. In both cases, local variation in temperature profiles at the glacier bed are driven by seasonal subglacial water fluxes and heat flow feedbacks between the ice surface slope and the ice bed, particularly in areas of overdeepening (Alley et al., 1999, 2003). Hallet $(1979,1996)$ proposed mechanical models for glacial abrasion and quarrying (plucking) that apply to glaciers whose basal ice has a relatively sparse load of rock fragments. As more material is excavated and entrained into the basal ice, the effective erosion slows because interactions between the particles in the foot of the glacier begin to dominate. Further erosion is limited by the capacity of subglacial water flux to transport abraded and plucked sediment out of the system so that fresh bedrock is continually exposed to further erosion. The integrated effects of these elements of glacial erosion give rise to glaciated valley morphometry.

In alpine terrain, local differences between abrasion and plucking combine with regional lithologic properties to form characteristic long profiles of glaciated valleys (Hooke, 1991; Augustinus, 1995; MacGregor et al., 2000; Brook et al., 2004). In general, long profiles of glaciated valleys are less concave than the profiles of fluvial valleys and are frequently stepped. Cirque headwalls and overdeepenings are genetically similar and result primarily by plucking of bedrock rather than abrasion (Hooke, 1991; Oskin and Burbank, 2005). The plucking of bedrock in overdeepenings is facilitated, in part, by the addition of 
meltwater via fractures in the ice, which contributes to variability in glacier velocity patterns and subsequent freeze-thaw dynamics related to pressure fluctuations in basal water pressure (Hooke, 1991; Alley et al., 1999, 2003). Blocks at the bed are loosened by pressure-release fracturing and crack propagation facilitated by the tremendous pressure differentials above the bedrock over small spatial scales, which result from freeze-thaw dynamics as the ice interacts with asperities on the bed (Hooke, 1991; Iverson, 1991). Modeling has shown that overdeepenings appear to also be governed by rapid increases in ice thickness at glacial confluences (MacGregor et al., 2000). The result is a pattern of bedrock erosion in which the glacier not only erodes downward, but where headward erosion often outpaces downward erosion (Hooke, 1991; Oskin and Burbank, 2005). The net result of both headward and downward erosion by glaciers is an overall lowering of the glacier bed over long periods of time.

\section{Study area}

The study area is located in south-central Idaho. The glaciated valleys lie in the Sawtooth Mountains, and the unglaciated valleys lie to the west in the South Fork Payette River basin in the southern Salmon River-Boise Mountains area (Fig. 1). The lithology of the area consists primarily of Cretaceous biotite granodiorite of the Idaho Batholith, Eocene biotite granite of the Sawtooth Batholith, and Eocene dikes of rhyolitic to andesitic composition, which locally form dense swarms (Hyndman, 1983; Fisher et al., 1992; Kiilsgaard et al., 2001). Hydrothermal alteration of the Idaho Batholith granodiorite is pervasive but variable, and is coeval with the Eocene Challis volcanic event, dike emplacement, and intrusion of the Sawtooth Batholith (Criss and Taylor, 1978; Taylor and Magaritz, 1978; Hyndman, 1983; Druschel and Rosenberg, 2001). Alteration, deep weathering, and local shearing have rendered the Idaho Batholith rocks into a weakly cohesive, highly erodible grus that is interspersed with less altered but rarely fresh granodiorite. Some of the steepest topography is underlain by resistant Eocene dike swarms (e.g., the South Fork Payette River Canyon below Lowman; Fig. 1).

A number of north- to northwest-striking normal faults of probable Miocene and younger age cut across the study region, the most prominent of which are the

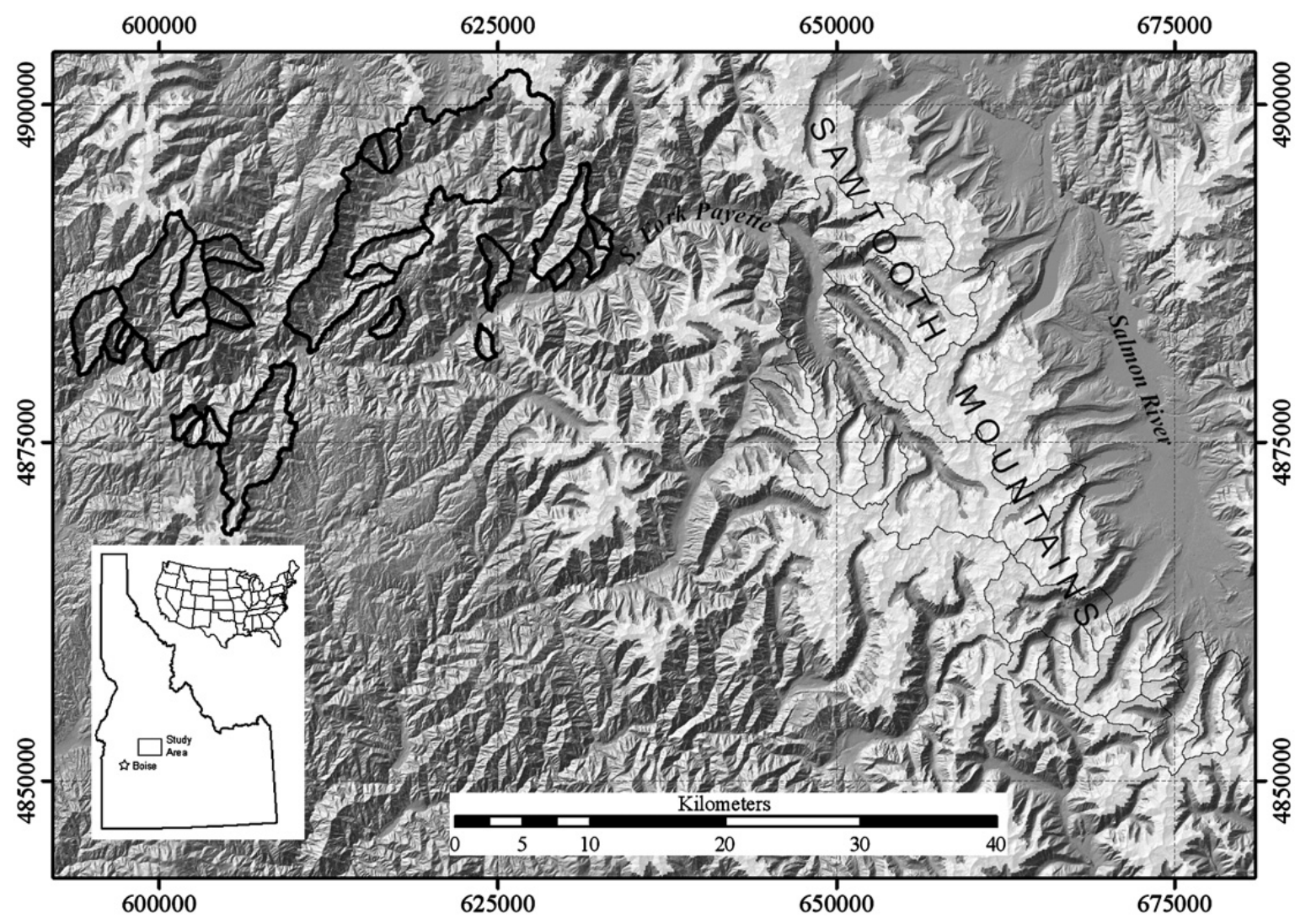

Fig. 1. Map of the study area in central Idaho. Polygons in heavy black represent the watershed boundaries of fluvial basins and thin black polygons are glaciated watersheds. The transparent white area represents topography that lies above the elevation of the regional ELA during the last glacial maximum. 
Deer Park and Sawtooth Faults bounding the higher elevations of the Sawtooth Range on the west and east, respectively (Breckenridge et al., 2003). Of these, only the Sawtooth Fault has produced major Quaternary displacement and is associated with a distinct mountain front and sediment-filled basin (Stanley Basin-Sawtooth Valley), but there is little evidence for significant late-Quaternary movement (Pierce and Morgan, 1992). Maximum relief in the glaciated study area basins, however, is somewhat less on the faulted eastern front of the Sawtooth Range $(\sim 1300 \mathrm{~m})$ than in major valleys on its western flank $(\sim 1700 \mathrm{~m})$. Maximum relief in the unglaciated basins along the South Fork Payette River is similar at about $1500 \mathrm{~m}$, such that there is no major difference in overall relief and base-level control, tectonic or otherwise, between the glaciated and unglaciated study areas.

Alpine glaciation was common throughout central Idaho, including in the Sawtooth Range and the highest peaks of the southern Salmon River and Boise Mountains, and glacial features such as cirques and moraines are widespread and abundant in these areas and adjacent ranges (e.g., Meyer et al., 2004). Moraine sequences in the region typically record between three and nine glacial advances during the Pleistocene (Evenson et al., 1982; Stanford, 1982; Colman and Pierce, 1986; Berry, 1987; Borgert et al., 1999; Thackray et al., 2004). The Sawtooth Mountains in particular were extensively glaciated. They form a prominent barrier to modern precipitation, and reconstructed late Pleistocene equilibrium line altitudes (ELAs) rise eastward across the study area from about 2250 to $2650 \mathrm{~m}$ (Meyer et al., 2004).

Thackray et al. (2004) used carbon dating of lake and bog sediment cores inside moraines of the eastern valleys of the Sawtooth Range to conclude that maximum advances occurred shortly before $16,900 \mathrm{cal}$ yr BP, after the LGM, with near-maximum ice extent maintained to as late as $14,000 \mathrm{yr}$ BP. How closely these minimum ages date terminal positions is uncertain, however. Thackray et al. (2004) infer that post-LGM advances were driven by increased winter precipitation rather than climatic cooling. They also show evidence for many glacial re-advances behavior consistent with wet-based alpine glaciers. Judging by their temperate latitude and moderate elevation, glaciers in the Sawtooth Range were most likely wet-based through most of their recent history.

The morphology of the selected fluvial valleys in the study area is predominantly erosional, with colluvial hollow fills on slopes and discontinuous stream sediments, footslope colluvium, and tributary alluvial fans in valley floors modestly influencing cross-sectional form. Field observations, including widespread bedrock-floored channels, indicate that sediments filling fluvial valleys of this study probably do not exceed a few tens of meters in thickness and are mostly much thinner. A few of the larger glacial valleys show evidence for large, unknown thicknesses of fill in their lower ends, e.g. in the South Fork Payette River and Alturas Lake Creek valleys (Fig. 1). In these areas, bedrock valley depth may substantially exceed the topographic valley depth.

The presence of geographically coincident glaciated and fluvial valleys with relatively homogeneous bedrock geology and similar base-level controls make southcentral Idaho favorable for this comparative study. Also, late Pleistocene equilibrium line altitude (ELA) data have been reconstructed for the entire study area (Meyer et al., 2004). Geologic maps, USGS digital elevation models, and recent aerial photos are all available for the study area, which hosts an extensive road and trail network that facilitated access to field reconnaissance sites. Combined with the presence of geographically coincident glaciated and fluvial valleys, these attributes make central Idaho ideal for the comparative study presented.

\section{Morphometric analyses}

Morphometric analyses used a composite of 67 individual U.S. Geological Survey 7.5-minute, 10-m grid digital elevation models (DEMs). The GIS software applications ArcGIS and ArcInfo workstation from ESRI were used for analysis. Anomalous low-points (sinks) in the DEM were filled using the "fill" function in the grid module in ArcInfo to produce a "filled" DEM raster ("grid"). Flow direction and flow accumulation grids were generated using the "flow direction" function and the "flow accumulation" function in the grid module in ArcInfo. Stream profiles were calculated for basins less than $10 \mathrm{~km}^{2}$ using a routine ("profix2.aml") that "walks" up and then down the stream valley and extracts the $x, y$, and $z$ coordinates, as well as flow accumulation for each point in the stream profile from the DEM, flow accumulation, and flow direction grids (H. Greenberg, University of Washington personal communication, 2004). The output from profix $2 . a m l$ was used to generate a spatially referenced table of $x, y$, and $z$ coordinates of stream profile points and flow accumulation at each point (a "point coverage" in ArcInfo). Individual study basin grids were generated with the "watershed" function in the grid package in ArcInfo. A spatially referenced table of $x, y$, and $z$ coordinates of 
watershed boundaries (a "polygon coverage" in ArcInfo) was generated using the study basin grids as a basis. Hillslope gradient distributions in the study basins were calculated using the "hillslope" function in the grid package in ArcInfo.

Twenty-one fluvial (unglaciated) and 25 glaciated basins (Fig. 1) were identified by DEM analyses, published mapping of moraines and glaciated terrain (Stanford, 1982), and inspection of digital raster graphics of aerial photographs (DRGs). Field reconnaissance of both fluvial and glaciated basins was also used in selection of study basins. The population of selected basins reflects the limited number of regionally proximate, glaciated and fluvial basins in the study area. Consequently, the mean drainage basin area of the two populations differs more than desired. In addition, because of valley fills of variable depth in the glaciated valleys of the study area, the measurements of local valley relief represent minimum measurements. The variable history of ice occupation in the glaciated valleys may also contribute to variability in the measure of local valley relief.

As an empirical check on the process history of the study basins, we used a map of the late Pleistocene regional ELA surface based on over 500 glacier reconstructions, with high data density in central Idaho (Meyer et al., 2004). We subtracted the regional topography $(10 \mathrm{~m}$ DEM) from the regional ELA surface to define topography that was above the elevation of the ELA. The area of the regional topography which lies above the ELA is depicted as a transparent white surface in Fig. 1. Basins that we defined as glaciated have large portions of their total area where the topography is higher than the regional ELA, and thus would have accumulated ice during the most recent glacial period. In contrast, most basins categorized as fluvial (Fig. 1) have maximum elevations well below the local ELA surface. A few have small areas near ridgelines that rise above the ELA surface, but these areas mostly have south to west aspects highly unfavorable for ice accumulation (Meyer et al., 2004). It is possible that small Pleistocene glaciers existed within the uppermost few kilometers of some of the largest fluvial basins, however, cirques are weakly developed if present, and the possibly glaciated areas represent a small proportion of these larger valleys.

Valley cross sections were created in ArcGIS by digitizing ridge-to-ridge, valley-spanning transects perpendicular to the long axis of valleys. Care was taken to select cross section sites away from the influence of confluences so as to minimize the effect of diminishing ridgeline elevations typical of valley junctions. The endpoints of the cross sections were snapped to the watershed boundaries in the polygon coverage of watersheds; this method allows unambiguous selection of cross section endpoints using natural gradient breaks of the landscape as represented in the DEM. Ridgelines were chosen as the upper boundaries of the cross sections, because even though the zone of direct erosional influence by a given process is confined to the bed of the glacier (Harbor, 1992) or river, either process can influences hillslope processes up to the ridgelines depending on rate of bed lowering and regional tectonic influence (e.g., Schmidt and Montgomery, 1995; Burbank et al., 1996; Aresenault et al., 2005; Oskin and Burbank, 2005). Valley cross-sectional profiles that had complicating factors, such as irregularities in form or grossly unequal subtending ridge elevations, were not selected for further analyses. Representative cross section profiles were selected from valley segments characterized by relatively uniform long profiles and straight valley walls.

The intersection of valley cross sections with the stream profile point coverage was used to find the drainage basin area associated with each cross section based on flow accumulation data in the point coverage. The cross sections were used to define zones from which elevation data were extracted from the DEM. The local valley relief for each cross section was calculated as the difference between the average elevation value of the two end points of the cross section line, which correspond to the valley ridgelines (the local maximum elevation) and the minimum elevation along each cross

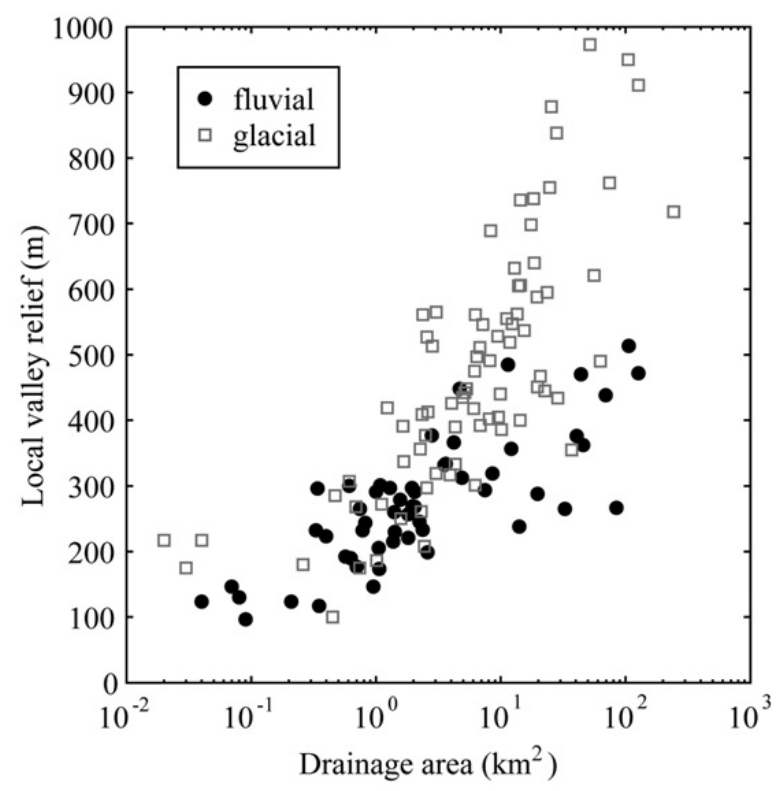

Fig. 2. Local valley relief versus drainage area in glaciated and fluvial basins of the Sawtooth Range of Idaho. Glaciated data are represented by open squares; fluvial data are represented by filled circles. 
Table 1

Summary table showing the results of regression of each valley morphometric parameter (relief, width, cross-sectional area) between fluvial and glacial valleys in central Idaho and in the Olympic Mountains of Washington

\begin{tabular}{|c|c|c|c|c|c|c|}
\hline Location and valley type & Morphometric variable & Intercept & $p$ value & Exponent & $p$ value & $R^{2}$ value \\
\hline Idaho glaciated & Relief (m) & 305 & $<0.0001$ & 0.20 & 0.065 & 0.63 \\
\hline Idaho fluvial & Relief (m) & 230 & $<0.0001$ & 0.16 & 0.065 & 0.60 \\
\hline Idaho glaciated & Width (m) & 1480 & $<0.0001$ & 0.14 & 0.546 & 0.54 \\
\hline Idaho fluvial & Width (m) & 1060 & $<0.0001$ & 0.14 & 0.546 & 0.51 \\
\hline Idaho glaciated & Cross-sectional area $\left(\mathrm{m}^{2}\right)$ & 263,030 & $<0.0001$ & 0.33 & 0.897 & 0.64 \\
\hline Idaho fluvial & Cross-sectional area $\left(\mathrm{m}^{2}\right)$ & 116,900 & $<0.0001$ & 0.31 & 0.897 & 0.59 \\
\hline Olympic glaciated & Relief (m) & 470 & 0.0056 & 0.17 & 0.237 & 0.70 \\
\hline Olympic fluvial & Relief (m) & 360 & 0.0056 & 0.14 & 0.237 & 0.62 \\
\hline Olympic glaciated & Width (m) & 1690 & 0.0015 & 0.21 & 0.946 & 0.78 \\
\hline Olympic fluvial & Width (m) & 1260 & 0.0015 & 0.21 & 0.946 & 0.80 \\
\hline Olympic glaciated & Cross-sectional area $\left(\mathrm{m}^{2}\right)$ & 371,080 & 0.0028 & 0.40 & 0.126 & 0.80 \\
\hline Olympic fluvial & Cross-sectional area $\left(\mathrm{m}^{2}\right)$ & $2,187,795$ & 0.0028 & 0.31 & 0.126 & 0.67 \\
\hline
\end{tabular}

Data for the Olympic Mountains are from Montgomery (2002b).

section. The area of each cross section was calculated using the trapezoid method, using the formula

$\operatorname{area}_{\mathrm{xs}}=\sum_{i=1}^{n}\left(L_{\mathrm{xs} i}\left(E_{\mathrm{max}}-E_{\mathrm{xs} i}\right)\right)$

where $E_{\max }$ is the average of the elevation of the two end points of the cross section, $E_{\mathrm{xs} i}$ is the elevation of the ground surface at each segment, $i$, along the cross section profile, and $L_{\mathrm{xs} i}$ is the width of each segment. Valley cross section lines were also used to generate cross section profiles that were then used to calculate local hillslope gradients. Local slopes for profile plots were determined from the angle from horizontal of the secant line that connected points placed at the base of the valley wall and the ridgeline above. The local hillslope relief at each site was also calculated using the same method as for local hillslope gradient. Valley morphometric data were log-transformed before analysis.

\section{Results}

Local valley relief increases with drainage area in both fluvial and glaciated basins, with values from fluvial basins plotting at lower relief values for comparable drainage areas (Fig. 2). For drainage areas less than $5 \mathrm{~km}^{2}$, the data from both valley types plot more or less indistinguishably. For drainage areas greater than $5 \mathrm{~km}^{2}$, relief in glaciated valleys begins to consistently exceed that in fluvial valleys. Fitting a power-law regression of the form $R=x A^{y}$ to each data sets yields

$$
\begin{aligned}
& R=230 A_{\mathrm{f}}^{0.15} \text { and } \\
& R=305 A_{\mathrm{g}}^{0.20}
\end{aligned}
$$

where $R(\mathrm{~m})$ is local valley relief and $A_{\mathrm{f}}$ and $A_{\mathrm{g}}$ are basin areas $\left(\mathrm{km}^{2}\right)$ for fluvial and glaciated drainages, respectively. Comparison of similarity in the intercept, $x$, and the exponent, $y$, of the log-transformed values between valleys formed by fluvial and glaciated processes resulted in $p$ values of $<0.0001$ for the intercept comparison and 0.0650 for the exponent comparison. Thus, the exponent of the relationship between local relief and area in glaciated valleys is not significantly different from that of fluvial valleys, but glaciated basins are about one-third deeper than fluvial valleys (Table 1). The value of the exponent suggests that relief in glaciated valleys increases more rapidly with respect to drainage area than in fluvial valleys.

Local valley width, $W$, also systematically increases with drainage area in both glaciated and fluvial valleys (Fig. 3). A power-law regression fit to the data yields

$$
\begin{aligned}
& W=1060 A_{\mathrm{f}}^{0.14} \text { and } \\
& W=1480 A_{\mathrm{g}}^{0.14} .
\end{aligned}
$$

Exponents on the relationships between the change in width and drainage area for the two valley types are similar, but the $p$ value of $<0.0001$ from the comparison of the intercepts shows that the intercepts are different, with glaciated valleys wider than fluvial valleys (Table 1).

Cross-sectional area increases with drainage area in both valley types. Power-law regression of the data yields the following equations, where $X$ is valley crosssectional area $\left(\mathrm{m}^{2}\right)$.

$X=2.6 \times 10^{5} A_{\mathrm{f}}^{0.33}$ and

$X=1.2 \times 10^{5} A_{\mathrm{g}}^{0.31}$. 
Regression of the log-transformed data results in a $p$ value of $<0.0001$ for the comparison of the intercepts, whereas there is no difference between the exponents with a $p$ value of 0.8970 (Table 1). Glaciated valleys have larger cross-sectional areas than fluvial valleys with the same drainage area, but cross-sectional areas increase no more rapidly in glaciated valleys than in fluvial valleys.

To help distinguish morphological differences between fluvial and glaciated valleys, we generated a cumulative frequency plot (Fig. 4) to show systematic differences in local valley slope gradient distributions in the different valley types. Fig. 4 shows plots of all basins of each type plotted together so that relative hillslope distributions can be observed between all of the basins. In general, the glaciated basins plot above the fluvial basins. This result is a function of the relatively large area of $U$ shaped glaciated basins that consist of flat-bottomed valleys. In contrast, nearly all of the fluvial valleys plot below the glaciated valleys as a function of the small area of the basin occupied by low-gradient terrain.

Plots of local hillslope relief versus local hillslope gradient in both glaciated and fluvial basins show that the glaciated valleys with the greatest relief have steeper slopes than the deepest fluvial valleys (Fig. 5). Following the method developed in Schmidt and Montgomery (1995), a curve fit to the upper edge of the data from fluvial valleys defines a limit to a topographic development (LTD). The curve is based on

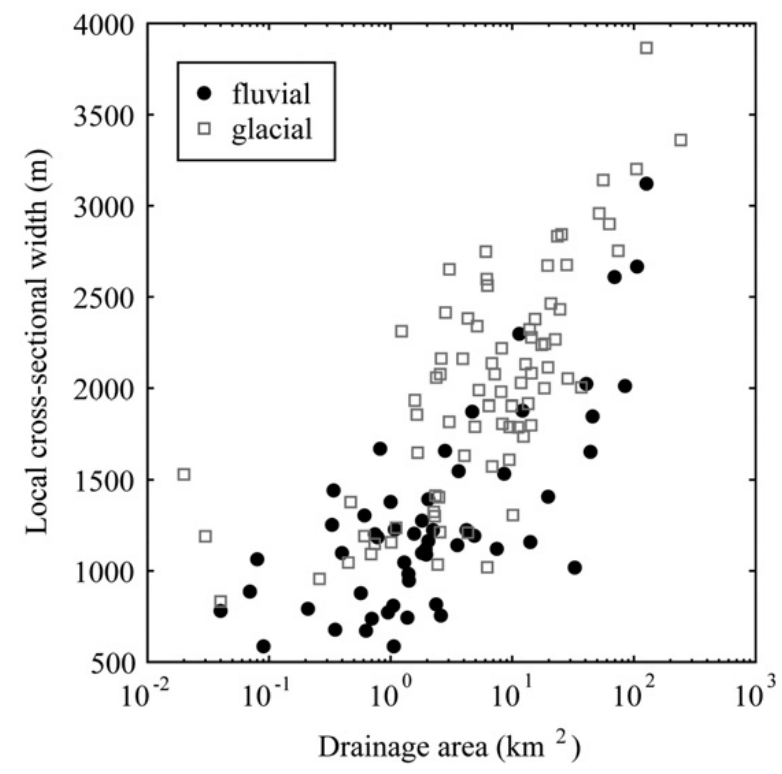

Fig. 3. Local valley cross section width versus drainage area in glaciated and fluvial basins of the Sawtooth Range of Idaho. Glaciated data are represented by gray open squares; fluvial data are represented by filled circles.

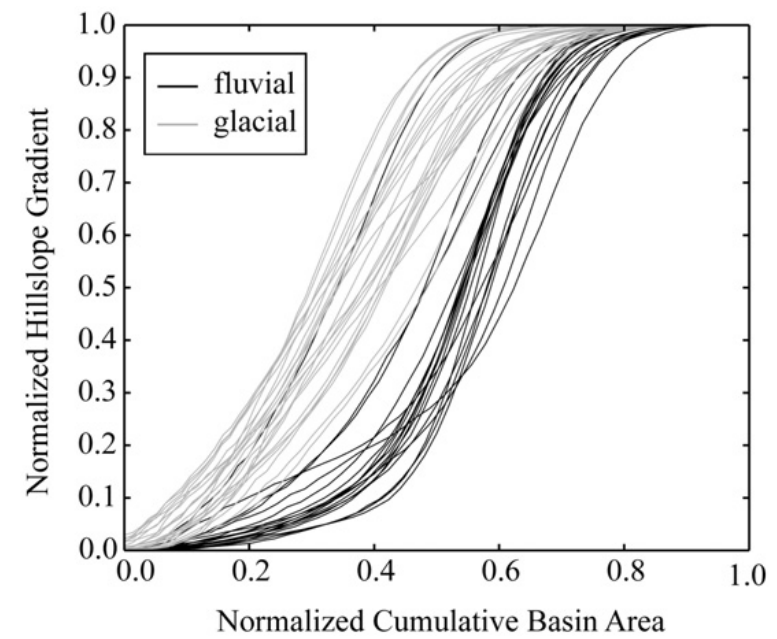

Fig. 4. Normalized hillslope gradient versus normalized cumulative basin area in glaciated and fluvial basins of the Sawtooth Range of Idaho. Gray lines represent glaciated basins; black lines represent fluvial basins.

Culmann's slope stability model (1866) and has the form,

$H_{c}=\frac{4 c}{\gamma} \frac{\sin \beta \cos \phi}{[1-\cos (\beta-\phi)]}$

where $c$ is cohesion, $\gamma$ is unit weight, $\phi$ is the internal friction angle, and $\beta$ is the slope angle. Iterative solutions of Eq. (8) using the range of slope angles in the study area to arrive at a best visual fit for the LTD arrived at values for $c=100 \mathrm{kPa}, \phi=20^{\circ}$, and $\gamma=26.5 \mathrm{kN} / \mathrm{m}^{3}$ for fluvial valleys, and $c=300 \mathrm{kPa}$, $\phi=25^{\circ}$, and $\gamma=26.5 \mathrm{kN} / \mathrm{m}^{3}$ for glaciated valleys.

\section{Local valley relief and erosion in glaciated and fluvial valleys}

Our analysis examines the down-valley relationship of local valley relief and width with drainage area in fluvial and glaciated basins in the mountains of central Idaho. To make comparisons of our results with another similar study, we chose to use data from the Olympic Mountains of Washington state (Montgomery, 2002b). Power-law relationships based on Montgomery's (2002b) data from the Olympic Mountains were generated using the same approach as for the Idaho data of this study (Table 1). Comparison of the power-law relationships from glaciated and fluvial valleys in the Olympic Mountains shows no difference in exponents for relief, width, and cross-sectional area, but similarly shows that glaciated valleys are deeper than fluvial valleys (Table 1). A comparison of relief, width, and cross-sectional area for glaciated and fluvial valleys between the Olympic Mountains and the 


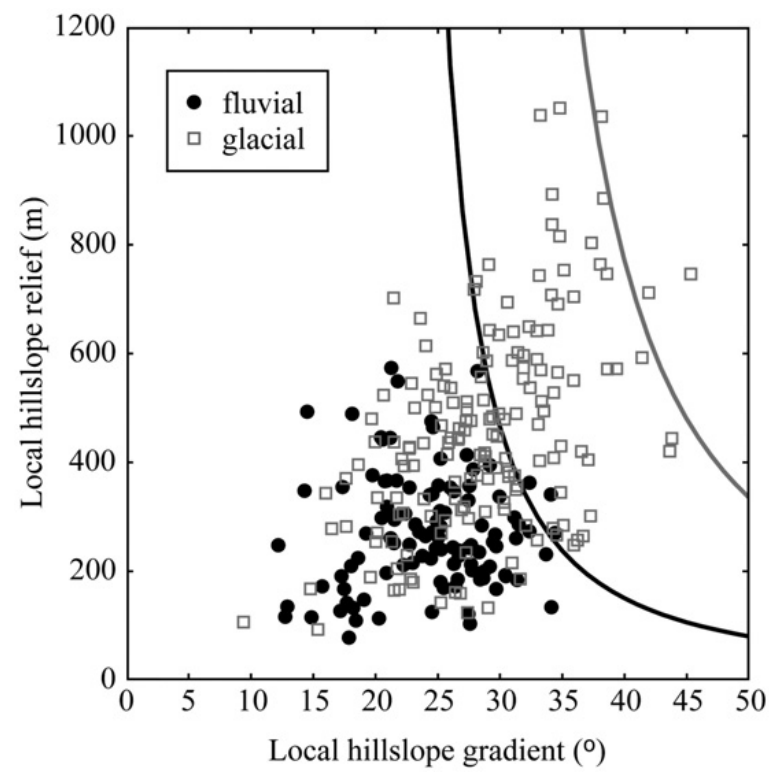

Fig. 5. Local hillslope relief versus local hillslope gradient in glaciated and fluvial basins of the Sawtooth Range of Idaho. Glaciated data are represented by open squares; fluvial data are represented by filled circles. The heavy line is the limit to topographic development (LTD) envelope. Critical parameters of the fluvial LTD (black) envelope are $c=100 \mathrm{kPa}$, $\phi=20$, and $g=26.5 \mathrm{kN} / \mathrm{m}$. Critical parameters of the fluvial LTD (gray) envelope are $c=300 \mathrm{kPa}, \phi=25$, and $g=26.5 \mathrm{kN} / \mathrm{m}$.

mountains of central Idaho shows that glaciated and fluvial valleys in the Olympic Mountains are deeper than in Idaho (Table 2).

Our results suggest that glacial erosion excavates deeper valleys than fluvial erosion both in Idaho and in the Olympic Mountains. Even though the rate of increase of valley depth is a function of similar slope coefficients in the power-law relationship, the relief plot shows that glaciated valleys are deeper than fluvial valleys in each region. Differences in the lithology and climate between central Idaho and coastal Washington give no reason to expect similarities in the intercepts of the data from the two regions, but the relationship between valley depth in glaciated and fluvial valleys holds for each region. The similarities in the ratio of the glaciated to fluvial intercepts in central Idaho (1.35) and the Olympic Mountains (1.31) suggest that glaciated valleys in both regions are about one-third deeper than fluvial valleys, despite obvious differences in lithology, tectonic setting, and climate. Specifically, the results from this study are directly comparable to those of Montgomery's (2002b) study of the morphology of glaciated and fluvial valleys in the Olympic Mountains, and are broadly comparable to those of Brocklehurst and Whipple (2002), who showed that glaciated valleys have greater relief than their fluvial counterparts.

The difference in local hillslope angle and local relief between glaciated and fluvial basins (Fig. 5) is a distinctive feature of the study area. Data from glaciated valleys not only spans but also plot well beyond the LTD envelope fit to data from fluvial valleys. The distribution of slopes in glaciated valleys shows that substantial portions of the basin are occupied by slopes steeper than the maximum slopes of the fluvial basins. In the steep terrain of mountain landscapes, landsliding limits the relief in landscapes at or above threshold slopes (Schmidt and Montgomery, 1995; Burbank et al., 1996; Montgomery, 2001; Dadson and Church, 2005). Field observation in the study area confirms that many glaciated valleys have experienced varying degrees of landsliding and that there is localized valley fill on the margins of glaciated valley walls, but many glaciated valleys maintain dramatic, sheer valley walls composed of bedrock with little or no cover of regolith.

Table 2

Summary table showing the results of regression of each valley morphometric parameter (relief, width, cross-sectional area) between fluvial valleys of central Idaho and the Olympic Mountains of Washington, and glacial valleys of central Idaho and the Olympic Mountains of Washington

\begin{tabular}{|c|c|c|c|c|c|c|}
\hline Location and valley type & Morphometric variable & Intercept & $p$ value & Exponent & $p$ value & $R^{2}$ value \\
\hline Idaho glaciated & Relief (m) & 305 & $<0.0001$ & 0.20 & 0.314 & 0.63 \\
\hline Olympic glaciated & Relief (m) & 470 & $<0.0001$ & 0.17 & 0.314 & 0.70 \\
\hline Idaho glaciated & Width (m) & 1480 & 0.1059 & 0.14 & 0.0064 & 0.54 \\
\hline Olympic glaciated & Width (m) & 1690 & 0.1059 & 0.21 & 0.0064 & 0.78 \\
\hline Idaho glaciated & Cross-sectional area $\left(\mathrm{m}^{2}\right)$ & 263,030 & 0.0506 & 0.33 & 0.1590 & 0.64 \\
\hline Olympic glaciated & Cross-sectional area $\left(\mathrm{m}^{2}\right)$ & 371,080 & 0.0506 & 0.40 & 0.1590 & 0.80 \\
\hline Idaho fluvial & Relief (m) & 230 & $<0.0001$ & 0.16 & 0.5950 & 0.60 \\
\hline Olympic fluvial & Relief (m) & 360 & $<0.0001$ & 0.14 & 0.5950 & 0.62 \\
\hline Idaho fluvial & Width (m) & 1060 & 0.0373 & 0.14 & 0.0590 & 0.51 \\
\hline Olympic fluvial & Width (m) & 1260 & 0.0373 & 0.21 & 0.0590 & 0.80 \\
\hline Idaho fluvial & Cross-sectional area $\left(\mathrm{m}^{2}\right)$ & 116,900 & 0.0006 & 0.31 & 0.7630 & 0.59 \\
\hline Olympic fluvial & Cross-sectional area $\left(\mathrm{m}^{2}\right)$ & $2,187,795$ & 0.0006 & 0.31 & 0.7630 & 0.67 \\
\hline
\end{tabular}

Data for the Olympic Mountains are from Montgomery (2002b). 
Numerical modeling by Dadson and Church (2005) suggests that while initial failure of oversteepened glaciated valley walls is rapid, the fluvial evacuation of accumulated valley fills lags behind landsliding inputs, which effectively buffers the base of valley walls from undercutting. We made a preliminary analysis of the amount of time required to transform valleys with glaciated morphology to valleys with fluvial morphology by using regional erosion rates for the study area. Erosion rates over $10^{3}-10^{6} \mathrm{yr}$ timescales in the study region are moderate, ranging from 0.05 to $0.1 \mathrm{~mm} \mathrm{yr}^{-1}$ (Sweetkind and Blackwell, 1989; Meyer and Leidecker, 1999; Kirchner et al., 2001). Given the sheer glaciated valleys in the study area, which range in relief from 200-900 m (Fig. 2), and moderate erosion rates, erosion of glaciated valleys to valleys with dominantly fluvial morphology is likely a process which takes on the order of tens of thousands of years at minimum. Considering that glacialinterglacial cycles during the Pleistocene have generally been about 100,000 years in duration (Shackleton et al., 1990), we suggest that glaciated topography is a persistent feature, and that glacial erosion is the dominant geomorphic agent setting local valley relief and valley spacing in glaciated mountains of the study area.

Hydrothermal alteration of the Idaho Batholith granodiorite is more prevalent in the fluvial valleys of this study and may contribute to differences in local valley relief between glaciated and fluvial valleys. The values for cohesion that were used to calculate the LTD for fluvial and glaciated valleys (Fig. 5) are 100 and $300 \mathrm{kPa}$, respectively. The value for cohesion $(C)$ used to fit an LTD envelope to glaciated valley data is higher than that for the fluvial valleys, but is still well below experimental values for samples of massive unweathered granite, which range from 35,000-474,000 $\mathrm{kPa}$ (Carmichael, 1989; Selby, 1993). The value for cohesion used in Eq. (8) for glaciated valleys may be reasonable if the rock of the Sawtooth has been exhumed relatively rapidly by glaciation and has undergone limited pressure-release fracturing or weathering since the most recent glaciation. Differences in local valley relief between glaciated and fluvial valleys of the Sawtooth region likely reflect both differences in the efficacy of glacial and fluvial erosion, combined with variability in the lithology resulting from hydrothermal alteration of the rock in the fluvial valleys and exhumation of fresh rock in the glaciated valleys.

\section{Conclusions}

Analysis of the morphometry of glaciated and fluvial basins of central Idaho shows that local valley relief, width, and cross-sectional area each scale with drainage area. Our morphometric analysis suggests that glacial erosion is more effective than fluvial erosion at excavating material to generate enhanced local valley relief, though the exponent on the relationship of relief relative to drainage area is similar. We also show that the ratio of the glaciated to fluvial intercepts in power-law relationships for local valley relief in valleys of the Olympic Mountains is close to our results in central Idaho, which suggests a consistent relationship between the morphometry of glaciated and fluvial valleys, despite variations in lithology, climate, and tectonic setting of different regions.

The distribution of hillslopes in fluvial and glaciated basins shows distinctive differences that relate to the typical valley form ascribed to the two erosional processes. Variability in local valley relief in glaciated basins may be a consequence of valley fill and variable degrees of erosion due the complex glacial history of the study area. Glaciated valleys leave oversteepened bedrock hillslopes, which initially fail rapidly. Because the time required to completely erase the topographic signature of glaciated erosion is probably on the order of many tens of thousands of years and therefore longer than the timescale of glacial-interglacial cycles, glaciated topography and enhanced valley relief should be geologically persistent features of alpine terrain of the study area.

\section{Acknowledgements}

Byron Amerson gratefully acknowledges the support of Beth Sanderson, Peter Kiffney, and NOAA Fisheries during early aspects of this research. We also thank Harvey Greenberg for invaluable GIS assistance and Alan Gillespie for insight that greatly improved early versions of this paper. Jon Francis provided assistance with statistical analyses. Derek Booth provided helpful editorial review.

\section{References}

Alley, R.L., Strasser, J.C., Lawson, D.E., Evenson, E.B., Larson, G.J., 1999. Glaciological and geological implications of basal ice accretion in overdeepenings. In: Mickelson, D.M., Attig, J.W. (Eds.), Glacial Processes Past and Present, vol. 337. Geological Society of America Special Paper, Boulder, CO.

Alley, R.L., Lawson, D.E., Larson, G.J., Evenson, E.B., Baker, G.S., 2003. Stabilizing feedbacks in glacier bed erosion. Nature 424, 758-760.

Aresenault, A.M., Miegs, A.J., Larson, 2005. Stabilizing contribution of deep-seated landslides to erosion of glaciated basin in southern Alaska. Earth Surface Processes and Landforms 30, 1111-1125.

Augustinus, P.C., 1995. Glacial valley cross-profile development: the influence of in situ rock stress and rock mass strength, with examples from the Southern Alps, New Zealand. Geomorphology 14, 87-97. 
Berry, M.E., 1987. Morphological and chemical characteristics of soil catenas on Pinedale and Bull Lake moraine slopes in the Salmon River Mountains, Idaho. Quaternary Research 28 (2), 210-255.

Borgert, J.A., Lundeen, K.A., Thackray, G.D., 1999. Glacial geology of the southeastern Sawtooth Mountains. In: Hughes, S.S., Thackray, G.G. (Eds.), Guidebook to the Geology of Eastern Idaho. Museum of Natural History, Pocatello, ID, pp. 205-217.

Breckenridge, R.M., Lewis, R.S., Adema, G.W., Weisz, D.W., 2003. Miocene and younger faults in Idaho. Idaho Geological Survey publication M-8.

Brocklehurst, S.H., Whipple, K.X., 2002. Glacial erosion and relief production in the Eastern Sierra Nevada, California. Geomorphology $42,1-24$.

Brook, M.S., Kirkbride, M.P., Brock, B.W., 2004. Rock strength and development of glacial valley morphology in the Scottish Highlands and northwest Iceland. Geografiska Annaler 86 (A(3)), 225-234.

Burbank, D.W., Leland, J., Fielding, E., Anderson, R.S., Brozovic, N., Reid-Mary, R., Duncan, C., 1996. Bedrock incision, rock uplift and threshold hillslopes in the northwestern Himalayas. Nature $379,505-510$.

Carmichael, R.S., 1989. Practical Handbook of Physical Properties of Rocks and Minerals. CRC Press, Boca Raton, FL. 741 pp.

Colman, S.M., Pierce, K.L., 1986. Glacial sequence near McCall, Idaho; weathering rinds, soil development, morphology, and other relative-age criteria. Quaternary Research 25 (1), 25-42.

Criss, R.E., Taylor, H.P., 1978. Regional ${ }^{18} \mathrm{O} /{ }^{16} \mathrm{O}$ and $\mathrm{D} / \mathrm{H}$ variations in granitic rocks of the southern half on the Idaho batholith and the dimensions of the giant hydrothermal systems associated with the emplacement of the Eocene Sawtooth and Rocky Bar plutons. Geological Society of America Abstracts with Programs 10 (7), 384.

Culmann, C., 1866. Die Graphische Statik. Zurich.

Dadson, J.S., Church, M., 2005. Postglacial topographic evolution of glaciated valleys: a stochastic landscape evolution model. Earth Surface Processes and Landforms 30, 1387-1403.

Druschel, G.K., Rosenberg, P.E., 2001. Non-magmatic fracture controlled hydrothermal systems in the Idaho batholith: South Fork Payette geothermal system. Chemical Geology 173, 271-291.

Evenson, E.B., Cotter, J.F.P., Clinch, J.M., 1982. Glaciation of the Pioneer Mountains: a proposed model for Idaho. In: Bonnichsen, B., Breckinridge, R.M. (Eds.), Cenozoic Geology of Idaho, vol. 26. Idaho Bureau of Mines and Geology Bulletin, Moscow, ID, pp. 653-665.

Fisher, F.S., McIntyre, D.H., Johnson, K.M., 1992. Geologic map of the Challis $1^{\circ} \times 2^{\circ}$ quadrangle, Idaho. USGS Miscellaneous Investigations Map I-1819, scale 1:250,000.

Goudie, A.S., 2002. Glacial erosion. In: Goudie, A.S. (Ed.), Encyclopedia of Geomorphology, vol. 2. Routledge, London and New York, pp. 840-842.

Gutenberg, B., Buwalda, J.P., Sharp, R.P., 1956. Seismic explorations on the floor of Yosemite Valley, California. Bulletin of the Geological Society of America 67, 1051-1078.

Hallet, B., 1979. A theoretical model of glacial abrasion. Journal of Glaciology 23 (8-9), 39-50.

Hallet, B., 1996. Glacial quarrying: a simple theoretical model. Annals of Glaciology 22, 1-8.

Harbor, J.M., 1992. Numerical modeling of the development of Ushaped valleys by glacial erosion. Geological Society of America Bulletin 104 (10), 1364-1375.

Harbor, J.M., 1995. Development of glacial-valley cross sections under conditions of spatially variable resistance to erosion. Geomorphology 14, 99-107.
Hooke, R.L., 1991. Positive feedbacks associated with erosion of glacial cirques and overdeepenings. Geological Society of America Bulletin 103, 1104-1108.

Hyndman, D.W., 1983. The Idaho batholith and associated plutons, Idaho and western Montana. In: Roddick, J.A. (Ed.), CircumPacific Plutonic Terranes, vol. 159. Geological Society of America Memoir, Boulder, CO, pp. 213-240.

Iverson, N.R., 1991. Potential effects of subglacial water-pressure fluctuations on quarrying. Journal of Glaciology 37 (125), 27-36.

Kirchner, J.W., Finkel, R.C., Riebe, C.S., Granger, D.E., Clayton, J.L., King, J.G., Megahan, W.F., 2001. Mountain erosion over 10yr, 10 k.y., and 10 m.y. time scales. Geology 29 (7), 591-594.

Kiilsgaard, T.H., Stanford, L.R., Lewis, R.S., 2001. Geologic map of the Idaho City $30 \times 60$ Quadrangle, Idaho. Idaho Geological Survey Publication GM-29, Moscow, ID.

Koppes, M., Hallet, B., 2006. Erosion rates during rapid deglaciation in Icy Bay, Alaska. Journal of Geophysical Research. 111 (F2), 11.

MacGregor, K.R., Anderson, R.S., Anderson, S.P., Waddington, E.D., 2000. Numerical simulations of glacial-valley longitudinal profile evolution. Geology 28 (11), 1031-1034.

Meyer, G.A., Leidecker, M.E., 1999. Fluvial terraces along the Middle Fork Salmon River, Idaho, and their relation to glaciation, landslide dams, and incision rates: a preliminary analyses and river mile guide. In: Hughes, S.S., Thackray, G.G. (Eds.), Guidebook to the Geology of Eastern Idaho. Museum of Natural History, Pocatello, ID, pp. 219-235.

Meyer, G.A., Fawcett, P.J., Locke, W.W., 2004. Late-Pleistocene equilibrium-line altitudes, atmospheric circulation, and timing of mountain glacier advances in the interior northwestern United States. In: Haller, K.M., Wood, S.H. (Eds.), Geological Field Trips in Southern Idaho, Eastern Oregon, and Northern Nevada. U.S. Geological Survey Open-File Report, Reston, VA, pp. 64-67.

Mitchell, S.G., Montgomery, D.R., 2006. Influence of a glacial buzzsaw on the height and morphology of the central Washington Cascade Range, USA. Quaternary Research 65, 97-107.

Montgomery, D.R., 2001. Slope distributions, threshold hillslopes, and steady-state topography. American Journal of Science 301 (4-5), 432-454.

Montgomery, D.R., 2002a. Relief. In: Goudie, A.S. (Ed.), Encyclopedia of Geomorphology, vol. 2. Routledge, London and New York, pp. 840-842.

Montgomery, D.R., 2002b. Valley formation by fluvial and glacial erosion. Geology 30 (11), 1047-1050.

Oskin, M., Burbank, D.W., 2005. Alpine landscape evolution dominated by cirque retreat. Geology 33 (12), 933-936.

Pierce, K.L., Morgan, L.A., 1992. The track of the Yellowstone hotspot: volcanism, faulting, and uplift. In: Link, P.K., Kuntz, M.A., Platt, L.B. (Eds.), Regional Geology of Eastern Idaho and Western Wyoming. Geological Society of America Memoir, vol. 179, pp. $1-53$.

Schmidt, K.M., Montgomery, D.R., 1995. Limits to relief. Science 270, 617-620.

Selby, M.J., 1993. Hillslope Materials and Processes. Oxford University Press, Oxford England. 451 pp.

Shackleton, N.J., Berger, A., Peltier, W.R., 1990. An alternative astronomical calibration of the lower Pleistocene time-scale based on ODP site 677a. Transactions of the Royal Society of Edinburgh. Earth Sciences 81, 251-261.

Small, E.E., Anderson, R.S., 1998. Pleistocene relief production in Laramide mountain ranges, western United States. Geology 26 (2), $123-126$. 
Stanford, L.R. 1982. Glacial geology of the upper South Fork, Payette River, south-central Idaho. Master's Thesis, University of Idaho, Moscow, ID, pp 83.

Sweetkind, D.S., Blackwell, D.D., 1989. Fission-track evidence of the Cenozoic thermal history of the Idaho batholith. Tectonophysics 157, 231-250.

Taylor Jr., H.P., Magaritz, M., 1978. Oxygen and hydrogen isotope studies of the Cordilleran batholiths of western North America. In: Robinson, B.W. (Ed.), Stable Isotopes in the Earth Sciences.
Bulletin of the New Zealand Department of Science and Industrial Research, Wellington, pp. 151-173.

Thackray, G.D., Lundeen, K.A., Borgert, J.A., 2004. Latest Pleistocene alpine glacier advances in the Sawtooth Mountains, Idaho, USA: reflections of midlatitude moisture transport at the close of the last glaciation. Geology 32 (3), 225-228.

Whipple, K.X., Kirby, E., Brocklehurst, S.H., 1999. Geomorphic limits to climate-induced increases in topographic relief. Nature 401, 39-43. 